Acta Botanica Brasilica - 30(3): 486-494. July-September 2016. doi: 10.1590/0102-33062016abb0154

\title{
Isolated trees with high crown coverage and densities increase pasture seed rain
}

\author{
Driélli de Carvalho Vergne', Hisaias Souza Almeida², Caroline Cambraia Furtado Campos', Natália. S. Martins ${ }^{3}$ and \\ Flavio Nunes Ramos ${ }^{*}$
}

Received: May 29, 2016

Accepted: August 17, 2016

\begin{abstract}
Pasture and crop lands restrict seed dispersal near remnant forest fragments, especially by restricting the movements of dispersal agents and limiting propagule dispersal. Some factors can improve seed dispersal in open areas, such as the presence of high numbers of isolated trees in close proximity to forest fragments. We sought to determine if: (i) the structural characteristics and (ii) densities of isolated trees in pasture lands, and (iii) their distances from the forest fragments, influence seed dispersal. We installed 18 seed traps in each of six pastures (total=108 traps) bordering forest fragments distributed over 6 distance classes from the forest edges (0, 5, 10, 20, 40 and 80 m). We determined the characteristics of the plants surrounding the traps. GLM and GLMer analyses were performed and the best model was selected by AIC. We collected 8162 seeds (4722 anemochorous, 3304 epizoochorous, 72 autochorous, and 64 endozoochorous) belonging to 26 species. Our results showed that plants with high crown coverage close to forest fragments and at high densities in the pastures increased seed dispersal. These results may aid future restoration of pasture lands by improving seed dispersal in this harsh habitat and promoting better connectivity between forest fragments.
\end{abstract}

Keywords: animal dispersal, crown coverage, isolated trees, pastures, seed rain

\section{Introduction}

Seed dispersal is crucial to plant regeneration (Janzen 1970) but can be negatively impacted by forest fragmentation - which has direct effects on animal populations and plant biodiversity (Galetti et al. 2003). Forest fragmentation and habitat loss, especially due to pasture establishment (Fahrig 2003; Fearnside 2005), results in the isolation of plant and animal populations by reducing forest habitats and promoting fragment isolation (Forman \& Godron 1986, Damschen et al. 2008). Additionally, the isolation of populations in forest fragments creates difficulties for the movement of pollination and dispersal agents (Tischendorf \& Fahrig 2001), restricting functional landscape connectivity (Roland et al. 2000; Ricketts 2001; Baum et al. 2004) and seed dispersal (Laurance et al. 2002).

Distance from the seed source can affect forest species propagule dispersal into pastures as seeds are not usually transported long distances from forest fragment edges (Aide \& Cavalier 1994; Holl 1999; Cubiña \& Aide 2001; Dosch et al. 2007; Martínez-Garza et al. 2009) or from their parent sources (Maarel 2005) without the help of dispersal agents. Thus, the presence of isolated trees in open pastures can help maintain biodiversity by facilitating the

\footnotetext{
${ }^{1}$ Laboratório de Ecologia de Fragmentos Florestais, Instituto de Ciências da Natureza, Universidade Federal de Alfenas, Rua Gabriel Monteiro da Silva, n.700, 37130-000, Alfenas, MG, Brazil

${ }^{2}$ Instituto de Recursos Naturais, Universidade Federal de Itajubá, Rua Dr. Pereira Cabral, n. 1303, 37500-903, Itajubá, MG, Brazil

${ }^{3}$ Instituto de Ciências Exatas, Universidade Federal de Alfenas, Rua Gabriel Monteiro da Silva, n.700, 37130-000, Alfenas, MG, Brazil

* Corresponding author: fnramos@gmail.com
} 
movements of dispersal agents between habitats (Benayas et al. 2008; Arroyo-Rodríguez et al. 2009; Cole et al. 2010). Additionally, the structural characteristics of plants that growing in pastures (such as their heights, diameters, crown coverage, and densities) will influence seed dispersal as tall, broad trees can provide shelter, nesting, and foraging sites (McDonnell 1986; Dean et al. 1999). Trees with wide and more highly branched crowns promote greater seed abundance beneath them (McDonnell \& Stiles 1983; Holl 1998; Cole et al. 2010; Derroire et al. 2016) and can serve as attractive environments for seed dispersers and will provide the immediate microclimate for seed germination and seedling growth (Belsky et al. 1989; Callaway 2007; Derroire et al. 2016). Trees with a larger diameters and hollows in their trunks are important for many bird species (Mazurek \& Zielinski 2004), and trees with larger diameters have greater crown coverage and more branches, and will produce more flowers and seeds (Chapman et al. 1992; Greene \& Johnson 1994).

The presence of isolated trees or clumps of plants in pastures can increase resource availability, improve the quality of the habitat by increasing the floristic and structural complexity of the landscape (Harvey et al. 2004), and increases the seed rain from neighboring forest plants (Harvey 2000; Peña-Domene et al. 2014). Additionally, plants growing in pastures will increase animal and seed movements and therefore improve the structural and functional connectivity of those fragmented habitats (Bennett et al. 1994; Forman 1995; Wunderle 1997; Metzger 2000; Godefroid \& Koedam 2003), accelerating plant succession (Peña-Domene et al. 2014).

The effects of isolated tree densities and the structural characteristics of individual trees on seed dispersal processes in pastures have only been poorly investigated (Guevara et al. 1992; Holl 1998; Dean et al. 1999; Slocum \& Horvitz 2000; Mazurek \& Zielinski 2004; Cole et al. 2010), and a better understanding of the characteristics of forest fragment connectivity in these areas could help efforts to improve seed dispersal and increase the biodiversity levels of those landscapes. We therefore sought to determine whether (i) the structural characteristics of trees growing in pastures, (ii) their densities, and (iii) their distances from forest fragments influence seed dispersal in pasture habitats. We hypothesized that there would be greater seed rain (in terms of both abundance and richness) dispersal: (i) closer to forest fragments, with seed abundance and richness being lower at greater distances from forest fragments (except with species that are wind dispersed) (Cubiña \& Aide 2001; Dosch et al. 2007; Martínez-Garza et al. 2009); (ii) in pastures with higher plant densities; and, (iii) around larger plants (with greater crown coverage, heights, and diameters), as both greater plant densities and larger plants would provide better sources of propagules and would attract more seed dispersal agents (Holl 1998; Dean et al. 1999; Duncan \& Chapman 1999; Mazurek \& Zielinski 2004; Cole et al. 2010).

\section{Materials and methods}

\section{Study area}

The present study was undertaken in six different areas (all within a $2 \mathrm{~km}$ radius) formed by forest fragments (20 to $40 \%$ forest cover) surrounded by active pastures. The six landscapes chosen (Tab. 1) had a wide range of isolated pasture tree densities (considering any tree in the pasture as a reference tree, and selecting individuals with $\mathrm{DBH}>5 \mathrm{~cm}$ ) (Fig. 1), and included 30 families and 90 species of trees/shrubs. Species richness ranged from five to 37 species per pasture. The families with the greatest numbers of individuals were Fabaceae (262), Asteraceae (61), Cannabaceae (57), Apocynaceae (37), Malvaceae (25), Lamiaceae (23), and Boraginaceae (21), which together accounted for almost $70 \%$ of the total number of trees. Most pasture trees were represented by small individuals, with approximately $75 \%$ of the trees having diameters $\leq$ $20 \mathrm{~cm}$ and $88 \%$ being less than $10 \mathrm{~m}$ tall. The mean tree diameter was $17.9 \mathrm{~cm}$ (ranging from 5 to $215 \mathrm{~cm}$ ) and the mean height was $7.1 \mathrm{~m}$ (ranging from 1.5 to $25 \mathrm{~m}$ ). In terms of their dispersal syndromes, anemochoric species accounted for $57 \%$ of the total number of trees and $33 \%$ of the total number of species, while zoochoric species represented $37 \%$ of the trees and $55 \%$ of the total number of species (Gonçalves et al. unpubl. res.).

The study area was situated in the semi-deciduous Atlantic Forest domain near Alfenas ( $45^{\circ} 56^{\prime}$ '50"W x $21^{\circ}$ $25^{\prime} 45^{\prime \prime}$ ) in Minas Gerais State, Brazil. The climate there

Table 1. Descriptions of pastures in southern Minas Gerais State, Brazil: municipalities, coordinates of pasture locations (DD $\left.{ }^{\circ} \mathrm{MM}^{\prime} \mathrm{SS}^{\prime}\right)$, and tree densities.

\begin{tabular}{|c|c|c|c|c|c|}
\hline Pasture & Regional names & Municipality & Longitude & Latitude & Tree density in pasture \\
\hline 1 & Matão & Alfenas & $40^{\circ} 95^{\prime} 45^{\prime \prime}$ & $76^{\circ} 21^{\prime} 88.0^{\prime \prime}$ & $3.65 / \mathrm{ha}$ \\
\hline 2 & Diniz & Alfenas & $38^{\circ} 13^{\prime} 66^{\prime \prime}$ & $76^{\circ} 28^{\prime} 49.4^{\prime \prime}$ & $16.00 / \mathrm{ha}$ \\
\hline 3 & P9 & Campos Gerais & $41^{\circ} 93^{\prime} 01^{\prime \prime}$ & $76^{\circ} 54^{\prime} 26.7^{\prime \prime}$ & 27.92/ha \\
\hline 4 & Luiz & Carmo do Rio Claro & $38^{\circ} 39^{\prime} 93^{\prime \prime}$ & $76^{\circ} 70^{\prime} 36.4^{\prime \prime}$ & $32.50 /$ ha \\
\hline 5 & $\mathrm{P} 13$ & Areado & $37^{\circ} 37^{\prime} 21^{\prime \prime}$ & $76^{\circ} 30^{\prime} 65.5^{\prime \prime}$ & 33.33/ha \\
\hline 6 & Zé Vânio & Campo do Meio & $40^{\circ} 21^{\prime} 73^{\prime \prime}$ & $76^{\circ} 60^{\prime} 76.8^{\prime \prime}$ & $83.57 /$ ha \\
\hline
\end{tabular}



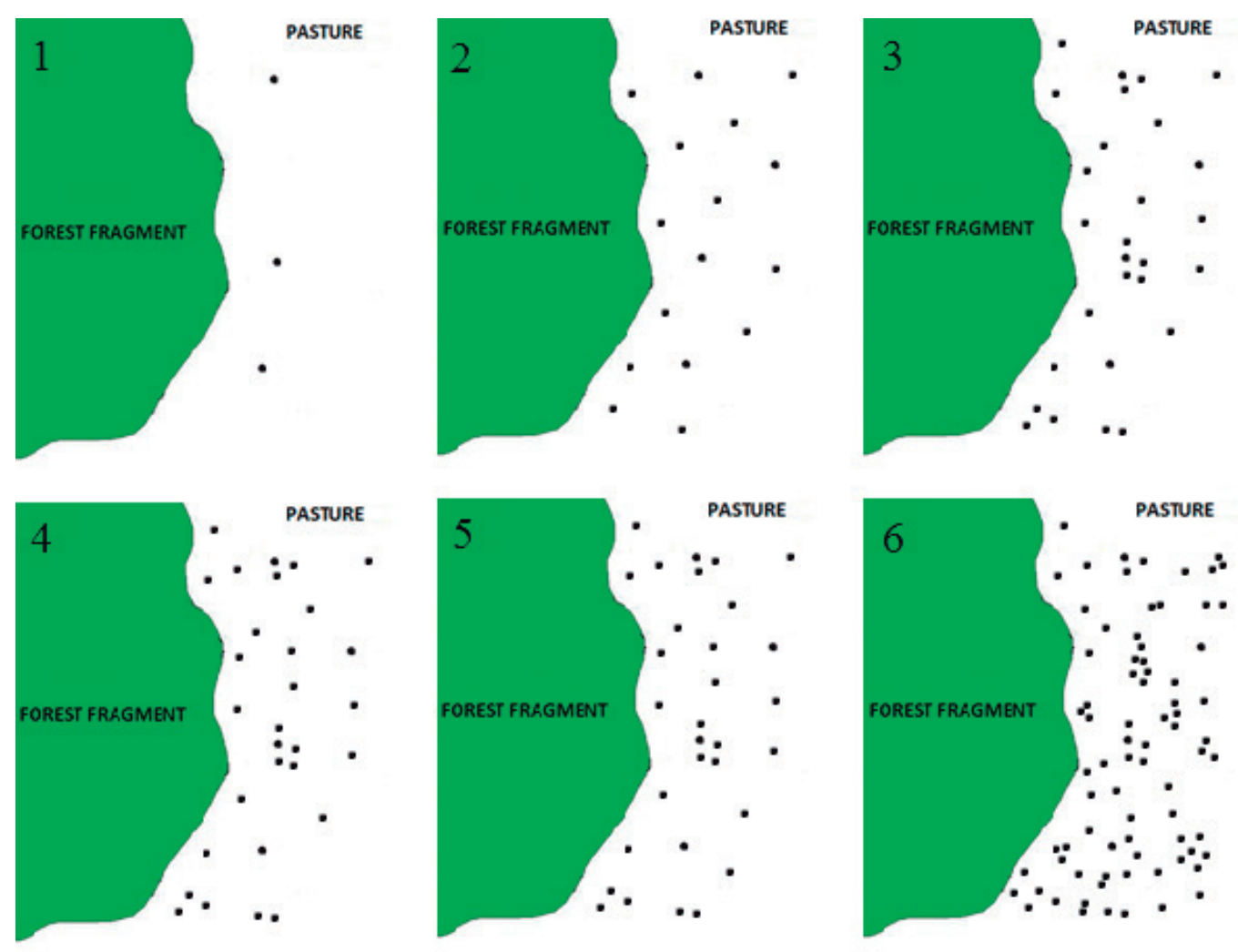

Figure 1. Six landscapes studied with varying isolated trees densities in each pasture. Pastures: 1(3.65 trees/ha), 2(16.00 trees/ha), 3(27.92 trees/ha), 4(32.50 trees/ha), 5(33.33 trees/ha) and 6(83.57 trees/ha).

is classified as Cwb (dry Austral winters and temperate summers) according to the Köppen-Geiger system, with a mean Austral winter temperature of $16.9^{\circ} \mathrm{C}$, and $21.5^{\circ} \mathrm{C}$ in the summer; the average monthly precipitation is $26 \mathrm{~mm}$ in the winter, and $290 \mathrm{~mm}$ in the summer (total annual precipitation: $1500 \mathrm{~mm}$ ) (Alvares et al. 2014). Regional elevations range from 720 to $1350 \mathrm{~m}$, with a predominantly hilly landscape. The study area contains fragmented forests, with only $~ 9 \%$ of their original cover; the fragments are surrounded by different agricultural matrices (such as coffee and sugar cane), urban areas, and a high percentage of pastures (Olivetti et al. 2015).

\section{Procedures}

We established three transects with six seed traps each (18 seed traps) in each of the six landscapes, giving a total of 108 traps. The seed traps were placed in the pastures at six different distances from the forest edge $(0,5,10,20,40$, and $80 \mathrm{~m}$ ) in each transect (Fig. 2). We considered distance $0 \mathrm{~m}$ as the point of transition from forest fragment to pasture. The transects were all established at least $150 \mathrm{~m}$ distant from each other (Fig. 2). The traps were composed of a square wire frame $(0.50 \mathrm{~m} \times 0.50 \mathrm{~m})$ with a nylon mesh $(1 \mathrm{~mm})$ stretched across it to collect and hold the seeds.
PVC pipes $(20 \mathrm{~mm}$ ) were positioned as supports to raise the frames $30 \mathrm{~cm}$ above ground level. The seeds collected in each trap were identified and classified according to APG III (2009); they were also classified according to their dispersal syndromes: anemochorous (wind dispersed), autochorous (self-dispersed), and endozoochorous (animal dispersed, after passing through their digestive tracts) (Pijl 1982) (Tab. 2). The seeds were harvested from the traps twice every month in March, April and May/2014. A circular plot $4 \mathrm{~m}$ in diameter was also defined around each trap and the tree and shrub densities, diameters at soil height (DSH - used here to include all trees and shrubs in those circular plots around the traps, especially those that had not been included as reference trees), their heights, and crown coverage (of all trees and bushes with heights greater than $1 \mathrm{~m}$ ) were determined (Tab. 3). Crown coverage was calculated at 1.30 $\mathrm{m}$ (breast height) using a plan densiometer in the center of each circular plot. There was significant variability in plant crown coverage and plant densities in the different pastures and at different distances from the forest fragment (Fig. 3).

\section{Data selection}

The six landscapes chosen presented a range of isolated pasture tree densities, as calculated using the ArcGIS 


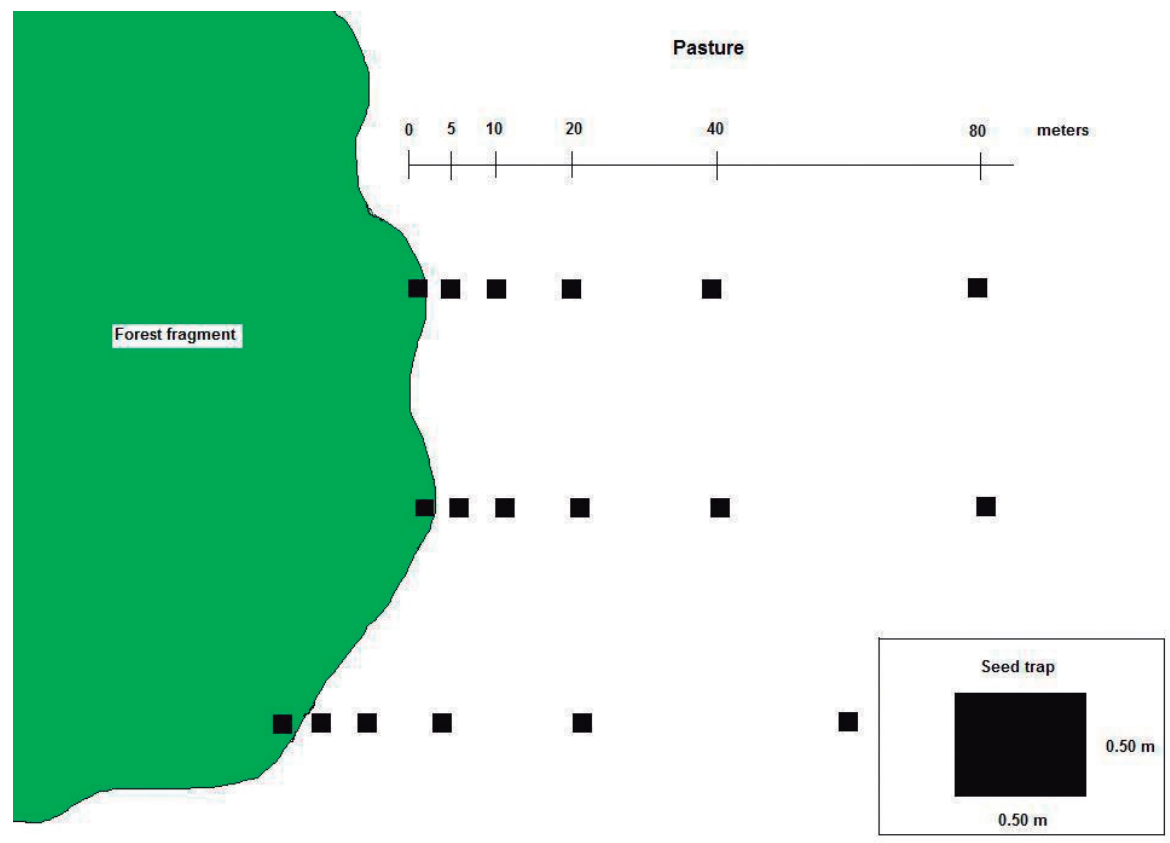

Figure 2. Sample layout of the seed trap transects in one of the 6 pastures. All transects were separated from each other by at least $150 \mathrm{~m}$.

platform (Version 10.0, ESRI). The independent variables (pasture parameters) used were: distance from the forest fragment; the densities of isolated trees in the pastures and isolated trees in the circular plots; and the structural characteristics of the plants (height, DSH, and crown coverage) around each seed trap. The dependent variables were seed richness and abundance. We did not transform the data. Vernonanthura sp. (an anemochorous species) was excluded from the analyses due to its outlier values (Tab. 2).

\section{Analyses}

We sought to understand how the independent variables such as the structural characteristics of plants (crown coverage, height and DSH), tree density (in pastures and in circular plots around the traps), and distance from the forest fragments influence the numbers and species richness of the seeds (dependent variables) collected in the seed traps. We first performed an autocorrelation test to filter for the independent variables not related to each other, these being: crown coverage (as a structural characteristic of the plants), distance from a forest fragment, tree densities in the pasture, and tree densities in the circular plots around the traps.

We used a generalized linear model (GLM) or generalized linear mixed model (GLMer), with a Poison distribution, to determine the relationships between the dependent variables (numbers and richness of the seeds), which were discrete, and the selected independent variables (refer to the paragraph above). We also included forest fragments as random factors in the model, as we were interested in understanding the influence of pasture tree characteristics (and not fragment or site quality). We used GLM in R, package bblme (Guisan \& Zimmermann 2000) and GLMer in R package lme4 9 (Bates et al. 2014).

Significant models were validated by normality and independence testing of the residues. Akaike Information Criterion (AIC) was used to assess model performance (Burnham \& Anderson 2001), with the best model being based on the lowest AIC value (Burnham \& Anderson 2001). We also considered other indices to evaluate model support by considering the difference between the model's AIC and the minimum AIC $(\triangle \mathrm{AIC})$. Models having $\triangle \mathrm{AIC}<2$ are considered to have substantial support and Akaike weights (wAIC), which describe the strength of the evidence for that model. This can be interpreted approximately as the probability that the model is the best model among the set of models being considered (Burnham \& Anderson 2001).

\section{Results}

We collect a total of 10,299 seeds in all of the traps (2,137 grass seeds and 8,162 non-grass seeds). There were 26 species and 15 families represented among the non-grass seeds, with Asteraceae (4,709 seeds, $57.7 \%)$ and Lamiaceae (3,214 seeds, $39.4 \%)$ being the most abundant; Fabaceae and Malvaceae (four species, $15.4 \%$ each) were the richest families. The most abundant species were Vernonanthura sp. (57.33\%) (Asteraceae) and Peltodon radicans (39.35\%) (Lamiaceae) (Tab. 2). When the collected seeds were separated by dispersal syndromes, there were 4,722 (57.8\%) 
Table 2. Distributions of the seed species according to their dispersal syndromes and total abundances. We excluded Vernonanthura $s p$. from the analyses as it showed outlier values. We also excluded all of the epizoochorous species, because they were not the target of our study.

\begin{tabular}{|c|c|c|c|c|c|c|}
\hline Species & Family & Dispersal syndrome & Disperser & Life form & Abundance & Abundance $\%$ \\
\hline Vernonanthura sp. & Asteraceae & Anemochorous & Wind & tree & 4680 & 57.339 \\
\hline Gochnatia sp. & Asteraceae & Anemochorous & Wind & shrub and/or tree & 20 & 0.245 \\
\hline Undeterminated 1 & Asteraceae & Anemochorous & Wind & herbaceous and/or shrub & 9 & 0.11 \\
\hline Machaerium sp. & Fabaceae & Anemochorous & Wind & shrub and/or tree & 8 & 0.098 \\
\hline Machaerium villosum & Fabaceae & Anemochorous & Wind & tree & 4 & 0.049 \\
\hline Serjania $s p$. & Sapindaceae & Anemochorous & Wind & vine & 1 & 0.012 \\
\hline Helicteres $s p$. & Malvaceae & Autochorous & & shrub & 5 & 0.061 \\
\hline Pilocarpus pennatifolius & Rutaceae & Autochorous & & tree & 4 & 0.049 \\
\hline Croton floribundus & Euphorbiacea & Autochorous & & tree & 2 & 0.025 \\
\hline Luehea divaricata & Malvaceae & Autochorous & & tree & 2 & 0.025 \\
\hline Cordia ecalyculata & Boraginaceae & Endozoochorous & Birds & tree & 25 & 0.306 \\
\hline Psychotria sp. & Rubiaceae & Endozoochorous & Birds & shrub & 18 & 0.221 \\
\hline Strychnos brasiliensis & Loganiaceae & Endozoochorous & Animals & tree & 4 & 0.049 \\
\hline Alchornea glandulosa & Euphorbiacea & Endozoochorous & Birds & tree & 3 & 0.037 \\
\hline Aegiphila integrifólia & Lamiaceae & Endozoochorous & Birds & shrub and/or tree & 2 & 0.025 \\
\hline Dicella bracteosa & Malpighiaceae & Endozoochorous & Not found & vine & 2 & 0.025 \\
\hline Undeterminated 2 & Arecaceae & Endozoochorous & Birds & tree & 1 & 0.012 \\
\hline Persea willdenovii & Lauraceae & Endozoochorous & Birds & tree & 1 & 0.012 \\
\hline Xylopia aromatica & Annonaceae & Endozoochorous & Birds & tree & 1 & 0.012 \\
\hline Peltodon radicans & Lamiaceae & Epizoochorous & & herbaceous and/or shrub & 3212 & 39.353 \\
\hline Sida sp. & Malvaceae & Epizoochorous & & herb and/or shrub & 34 & 0.417 \\
\hline Desmodium sp. & Fabaceae & Epizoochorous & & shrub & 32 & 0.392 \\
\hline Triumfetta semitriloba & Malvaceae & Epizoochorous & & shrub & 21 & 0.257 \\
\hline Mimosa sp. & Fabaceae & Epizoochorous & & shrub & 5 & 0.061 \\
\hline
\end{tabular}

Table 3. Mean (minimum - maximum) values of the parameters of the isolated trees surveyed in the circular plots surrounding each trap, in six sites in Minas Gerais State, Brazil.

\begin{tabular}{|c|c|c|c|c|c|c|c|}
\hline Site & $\begin{array}{l}\text { Maximum } \\
\text { height }[m]\end{array}$ & $\begin{array}{c}\text { Mean } \\
\text { height }[\mathrm{m}]\end{array}$ & $\begin{array}{l}\text { Basal area } \\
{\left[\mathrm{cm}^{2}\right]}\end{array}$ & $\begin{array}{c}\text { Plant density } \\
\text { [number of } \\
\text { individuals] }\end{array}$ & $\begin{array}{l}\mathrm{DSH}^{\star} \\
{[\mathrm{cm}]}\end{array}$ & $\begin{array}{c}\text { Crown coverage } \\
{[\%]}\end{array}$ & $\begin{array}{c}\text { Cover** } \\
{[\%]}\end{array}$ \\
\hline P9 & $3.0(1.8-9.0)$ & $2.3(1.7-9.0)$ & $9780.1(147.5-38542.4)$ & $3.7(0.0-13.0)$ & $23.5(4.0-90.0)$ & $31.9(0.0-79.3)$ & $42.3(0.0-100.0)$ \\
\hline Luiz & $4.0(3.1-12)$ & $1.5(3.0-5.0)$ & $2248.2(458.7-9537.1)$ & $1.6(0.0-5.0)$ & $6.1(16.0-22.5)$ & $26.8(0.0-81.5)$ & $28.2(0.0-90.0)$ \\
\hline P13 & $2.2(1.8-7)$ & $1.5(1.8-4.3)$ & 2161.7 (35.5-9476.6) & $1.8(0.0-6.0)$ & $10.8(4.8-42.7)$ & $35.4(0.0-85.3)$ & $39.5(0.0-100.0)$ \\
\hline Pmatâo & $2.0(1.7-7)$ & $1.7(1.7-4.8)$ & $956.8(19.6-4158.7)$ & $0.8(0.0-2.0)$ & $7.7(3.5-26.7)$ & $25.0(0.0-86.8)$ & $30.6(0.0-100.0)$ \\
\hline Pdiniz & $2.3(4.0-8.0)$ & $1.3(2.6-4.2)$ & $491.4(654.2-2006.7)$ & $1.5(0.0-5.0)$ & $8.3(11.8-31.2)$ & $29.1(0.0-83.3)$ & $32.2(0.0-100.0)$ \\
\hline
\end{tabular}

* DSH: diameter at soil height used to include all trees and shrubs surrounding the traps.

** Cover: similar to crown coverage measurements under the circular plots, but we considered the shaded area under each trap in the circular plots.

anemochorous seeds, 3,304 (40.5\%) epizoochorous, 72 (0.9\%) autochorous, and $64(0.8 \%)$ endozoochorous propagules.

Six species and five families of anemochorous seeds were collected. The most abundant anemochorous species was Gochnatia sp. (0.24\%). Autochorous seeds were represented by five species and three families, with the most abundant species being Croton urucurana (0.72\%). Endozoochorous seeds were represented by 10 species and 10 families, with the most abundant species being Cordia ecalyculata (39.06\%) and Psychotria sp. (28.13\%). Almost all of the species were dispersed by birds; only two species were undefined (Tab. 2). Plant densities (circular plots) and their percentages of crown coverage exhibited the same patterns of distribution in the six different pasture areas studied (pastures with their respective numbers of trees per hectare) (Fig. 3 A-B). A similar distribution pattern also occurred when we plotted the plant density and crown coverage at different distances from the forest fragments (positions of the traps) (Fig. 3 C-D). 

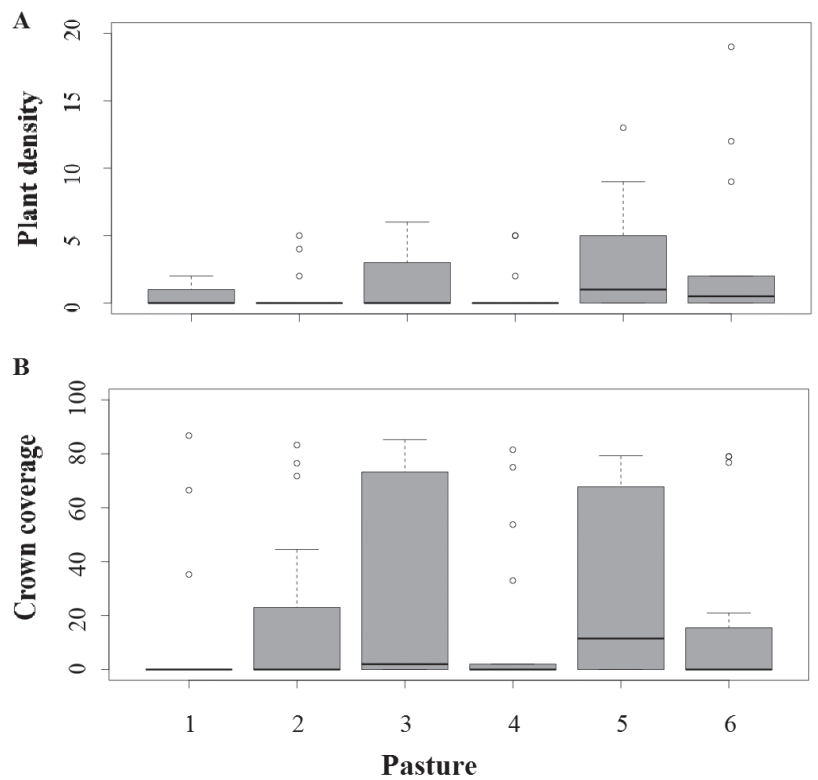

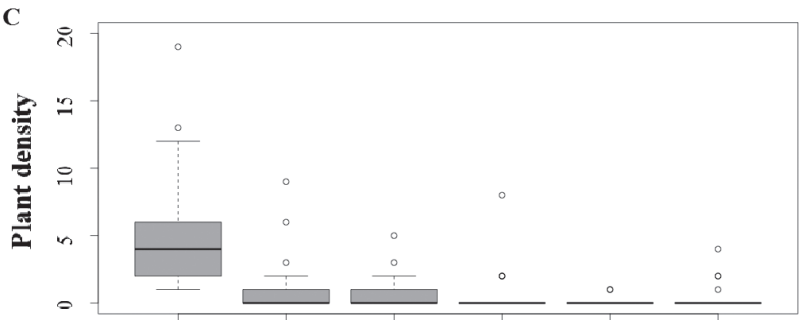

D

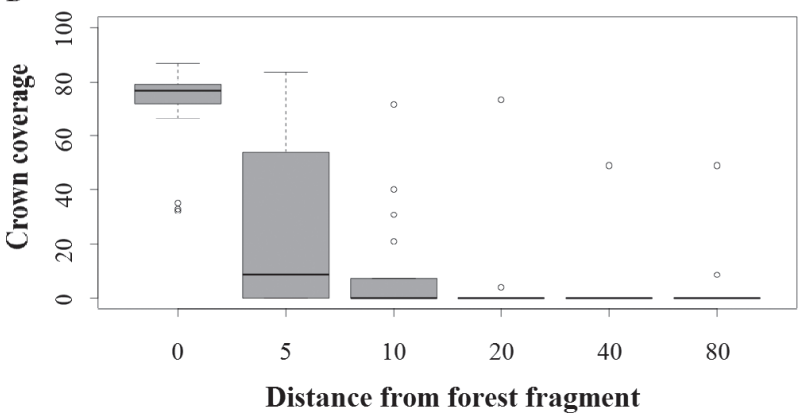

Figure 3. A and B - number of plants and percentage of crown coverage distributed in six different landscapes, respectively (six pastures with different number of isolated trees per hectare; pastures: 1 (3.65 trees/ha), 2(16.00 trees/ha), 3(27.92 trees/ha), 4(32.50 trees/ha), 5(33.33 trees/ha) and 6(83.57 trees/ha), respectively); C and D - mean of plants and percentage of crown coverage in six different distances from edge forest fragment in all pastures, respectively.

Crown coverage showed a strong effect on the seed rain either alone or with (interacting with) other landscape characteristics in terms of the seed dispersal syndromes. This variable was present in the best models $(\triangle \mathrm{AIC} c<2$, wi< 0.001), with significant effects on both seed richness and abundance (Tab. S1 in supplementary material). There were positive relationships between crown coverage and (i) total seed richness (all seed dispersal syndromes), as well as with anemo-, auto-, and endozoochorous seeds; and (ii) with seed abundance, but always with interactions with another independent variable.

Total seed abundance increased under trees with greater crown coverage in pastures with high tree densities. The abundance of endozoochorous seeds increased, in turn, in three different situations: (i) in areas (in circular plots) with high plant densities and with high crown coverage; (ii) in areas (circular plots) with high plant densities in pastures with high tree densities; and (iii) in pastures with high tree densities with plants with high crown coverage.

These results corroborate our initial hypothesis that the seed rain (seed richness and abundance) is greater beneath trees with greater crown coverage and in areas with higher tree densities. Our hypothesis, however, was not corroborated in two cases: first the seed abundance of autochorous tree species increased when pasture trees were further from the forest fragments and showed high crown coverage; secondly, the seed abundance of anemochorous species was lower in seed traps more distant from the forest fragments. Finally, the seed abundance of anemochorous species increased when there were high tree densities in the pastures and high crown coverage (Tab. S2 in supplementary material).

\section{Discussion}

Our results show that pasture seed rain is greatest: (i) with high crown coverage, (ii) with high tree/shrub densities, and (iii) at short distances from the forest fragments. High crown coverage will increase the total seed rain, as well as all of the seed dispersal syndromes considered (anemochory, autochory, and endozoochory). Other studies have likewise found greater seed abundances under trees with greater crown coverage (Cole et al. 2010) and under trees with more branches (McDonnell \& Stiles 1983; Holl 1998). High crown coverage promotes better conditions for the dispersal agents of endozoochorous syndromes, by providing food resources (Luck \& Daily 2003), resting and nesting sites, a more amenable microclimate, and protection from predators (Wegner \& Merriam 1979; McDonnell \& Stiles 1983; McClanahan \& Wolfe 1987; Callaway 2007; Derroire et al. 2016). Additionally, high crown coverage with greater tree densities (both in open pasture and within the circular plots) will increase the abundance of both the total and the endozoochorous seed rain. Autochorous and anemochorous plants with high crown coverage and also provide more abundant sources of propagules for the seed rains (McDonnell 1986; Guevara et al. 1992; Duncan \& Chapman 1999) of those two syndromes.

High plant densities (both trees and shrubs), especially associated with high crown coverage, will promote greater total, anemo-, and endozoochorous seed rains in pasture areas. The pastures studied here showed a preponderance of anemochorous seeds because most (63\%) of the isolated 
trees there (Gonçalves et al. unpubl. res.) demonstrated that specific seed dispersal syndrome. Vieira et al. (2002) and Griz et al. (2002) likewise found that anemochorous species develop better in open areas (which are normally drier environments) than in forest sites.

The presence and the densities of isolated trees in pastures are very important for endozoochorous dispersal. Seed dispersal in open areas is difficult for endozoochorous forest species because most disperser animals show restricted movements across pastures due to their unfavorable microclimates and the greater risk of predation. Although this was a logical and expected result, this study is the first to demonstrate the importance of isolated trees to seed dispersal in pastures, and to indicate which of their structural characteristics (crown coverage) improved seed rain in that habitat. Tewksbury et al. (2002) found that fruit production and seed movement was greater among connected fragments (South Carolina, USA) than non-connected fragments. Nason \& Hamrick (1997) likewise demonstrated that small fragments and isolated trees function as important stopping points for seed dispersers in fragmented landscapes. Isolated trees can promote greater movement of seed dispersal agents through open areas, and act as stepping stones for forest birds in fragmented landscapes (Nepstad et al. 1996; Perfecto et al. 1996). Harvey (2000) found greater seed dispersal under isolated trees and shrubs in Costa Rica because they provided perches for birds. Isolated trees can offer nutritional rewards (Luck \& Daily 2003), good perches, singing sites, nesting sites, and protection from predators (Wegner \& Merriam 1979; McDonnell \& Stiles 1983; McClanahan \& Wolfe 1987). Thus, pastures with isolated trees provide food resources, refuge sites, and shade for cattle and wild birds (Harvey \& Haber 1999), and pastures with high tree densities should also increase seed rain and accelerate successional processes (Peña-Domene et al. 2014).

The positive relationship found between distance from a forest fragment and the seed abundance of autochorous tree species, as observed in the present study, was probably due to the presence of isolated trees or shrubs in those pastures presenting autochorous syndrome. Therefore, some of the seed sources were these isolated trees and shrubs, which generate this pattern of seed dispersal. Seeds of autochorous species tend to show aggregated dispersal patterns that limit long distance seed dispersal (Wilson 1993; Giehl et al. 2007).

Their normal short-distance seed dispersal capacity indicates that there were probably adult trees of those autochorous species producing seeds near some of the most distant traps. However, this pattern was consistent for many of the autochorous species, and there was no overall relationship between autochorous seed richness and distance from the forest fragments. The seeds of only two autochorous species, Croton floribundus and Croton urucarana, were collected in pasture traps.
The abundance of anemochorous seeds showed a negative relationship with distance from the forest fragments. Anemochorous seeds require wind action to be dispersed over long distances, but our study was undertaken in March, April and May - months when there is little wind in that region. Additionally, tall isolated trees showing other syndromes could function as physical barriers to anemochorous seed dispersal.

In general, we collected a considerable number of seed samples, and our results offer interesting initial theoretical and practical advances that encourage longer studies that could answer additional questions about the movements of seed dispersal agents through pastures. Our study, and its results, have some restrictions, however, that should be considered. We studied factors that could influence seed dispersal (seed rain) in pastures, although germination, seedling survival, and growth will be affected by many other parameters that were not investigated. Additionally, our study was conducted over a relatively short period of time and occurred during poor months for seed production (the dry season), and at a time of year without fruiting peaks of species showing anemochorous and endozoochorous syndromes (Vergne et al. unpubl. res.). We did, however, demonstrate valid relationships between a number of plant and pasture characteristics that may be accentuated when the fruiting peaks of these species occur. The present results will help us to understand how seed dispersal occurs during the dry season and allow us to presume that the presence of isolated plants with high crown coverage and densities will promote greater seed rains in pastures. A number of authors have shown that isolated trees have important roles in pastures, such as improving microclimate conditions (Callaway 2007; Derroire et al. 2016), increasing soil nutrient levels (Belsky et al. 1989; Guevara \& Laborde 1993; Sarmiento 1997; Rhoades et al. 1998; Otero-Arnaiz et al. 1999), facilitating forest recovery (Holl et al. 2000; Peña-Domene et al. 2014) and serving as stepping stones for species movements between forest fragments.

Our results described some important characteristics of individual plants that tend to improve seed dispersal in open matrices of fragmented landscapes, and the positive influence of high tree densities on seed dispersal (Benayas et al. 2008; Cole et al. 2010; Peña-Domene et al. 2014) - with high crown coverage and high plant densities (trees and shrubs) being very important to seed rains in pastures. In conclusion, seed dispersal in pastures depends primarily on crown coverage, and secondarily on pasture plant densities and the distance to the forest fragment. Seed rain (seed abundance and richness) in pastures can be improved by the presence of greater numbers of isolated trees and shrubs, especially if they have broad crown coverage. Introducing trees that produce large crowns in open matrices between forest fragments would improve seed movement as well as the connectivity of those fragments, improving biodiversity in fragmented areas and promoting the regeneration of native vegetation in abandoned pastures. 


\section{Acknowledgements}

We thank Dr. Geraldo Franco of the Forest Institute of São Paulo for his help in identifying the collected seeds, J. Elias, M. Zanatta, T. Gonçalves, P. Carlstrom, and G. Zaccarin who helped with the fieldwork, as well as Roy Funch for correcting the English version of this manuscript. We also thank CAPES; PNPD/CAPES (23038.006963/2011) and FAPEMIG/VALE (CRA- RDP-0104-10) for the grant and financial support of this research.

\section{References}

Aide TM, Cavelier J. 1994. Barriers to Lowland Tropical Forest Restoration in the Sierra Nevada de Santa Marta, Colombia. Restoration Ecology 2: 219-229.

Alvares CC, Stape JL, Sentelhas PS, Gonçalves JLM, Sparovek G. 2014. Köppen's climate classification map for Brazil. Meteorologische Zeitschrift 22: 711-728.

APG III - Angiosperm Phylogeny Group. 2009. An update of the Angiosperm Phylogeny Group classification for the orders and families of flowering plants: APG III. Botanical Journal of the Linnean Society 161: 105-121.

Arroyo-Rodríguez V, Pineda E, Escobar F, Benitez-Malvido J. 2009. Value of small patches in the conservation of plant-species diversity in highly fragmented rainforest. Conservation Biolology 23: 729-739.

Bates D, Maechler M, Bolker B, Walker S. 2014. lme4: Linear mixed-efects models using Eigen and S4. R package version 1.1-6.

Baum KA, Haynes KJ, Dillemuth FP, Cronin JT. 2004. The matrix enhances the effectiveness of corridors and stepping stones. Ecology 85: 26712676.

Belsky AJ, Admunson RG, Duxbury JM, Riha SJ, Ali AR, Mwonga SM. 1989. The effects of trees on their physical, chemical, and biological environments in a semi-arid savanna in Kenya. Journal of Applied Ecology 26: 1005-1024.

Benayas JMR, Bullock JM, Newton AC. 2008. Creating woodland islets to reconcile ecological restoration, conservation, and agricultural land use. Frontiers in Ecology and the Environment 6: 329-336.

Bennett AF, Henein K, Merriam G. 1994. Corridor use and the elements of corridor quality: chipmunks and fencerows in a farmland mosaic. Biological Conservation 68: 155-165.

Burnham KP, Anderson DR. 2001. Kullback-Leibler information as a basis for strong inference in ecological studies. Wildlife Research 28: $111-119$.

Callaway RM. 2007. Positive interactions and interdependence in plant communities. Dordrecht, Springer.

Chapman CA, Chapman LJ, Wrangham RW, Hunt K, Gebo D, Gardner L. 1992. Estimators of fruit abundance of tropical trees. Biotropica 24: 527-531.

Cole RJ, Holl KD, Zahawi RA. 2010. Seed rain under tree islands planted to restore degraded lands in a tropical agricultural landscape. Ecological Applications 20: 1255-1269.

Cubiña A, Aide TM. 2001. The Effect of Distance from Forest Edge on Seed Rain and Soil Seed Bank in a Tropical Pasture. Biotropica 33: 260-267.

Damschen EI, Brudviga LA, Haddadb NM, Leveyc DJ, Orrocka JL, Tewksburyd JJ. 2008. The movement ecology and dynamics of plant communities in fragmented landscapes. Proceedings of the National Academic of Science 49: 19078-19083.

Dean WRJ, Milton SJ, Jeltsch F. 1999. Large trees, fertile islands, and birds in arid savanna. Journal of Arid Environments 41: 61-78.

Derroire G, Coe R, Healey JR. 2016. Isolated trees as nuclei of regeneration in tropical pastures: testing the importance of niche-based and landscape factors. Journal of Vegetation Science 27: 679-691.

Dosch JJ, Peterson CJ, Haines BL. 2007. Seed rain during initial colonization of abandoned pastures in the premontane wet forest zone of southern Costa Rica. Journal of Tropical Ecology 23: 151-159.
Duncan RS, Chapman CA. 1999. Seed dispersal and potential forest succession in abandoned agriculture in tropical Africa. Ecological Applications 9: 998-1008.

Fahrig L. 2003. Effects of habitat fragmentation on biodiversity. Annual Review of Ecology, Evolution and Systematics 34: 487-515.

Fearnside PM. 2005. Deforestation in Brazilian Amazonia: history, rates, and consequences. Conservation Biology 19: 680-688.

Forman RTT. 1995. Land mosaics: the ecology of landscapes and regions. London, Cambridge University Press.

Forman RTT, Godron M. 1986. Landscape Ecology. New York, John Wiley and Sons, Inc.

Galetti M, Alves-Costa CP, Cazetta E. 2003. Effects of forest fragmentation, anthropogenic edges and fruit colour on the consumption of ornithocoric fruits. Biological Conservation 111: 269-273.

Giehl ELH, Athayde EA, Budke JC, Gesing JPA, Einsiger SM, Canto-Dorow TS. 2007. Espectro e distribuição vertical das estratégias de dispersão de diásporos do componente arbóreo em uma floresta estacional no sul do Brasil. Acta Botanica Brasilica 21: 137-145.

Godefroid S, Koedam N. 2003. How important are large vs. small forest remnants for the conservation of the woodland flora in an urban context? Global Ecology and Biogeography 12: 287-298.

Greene DF, Johnson EA 1994. Estimating the mean annual seed production of trees. Ecology 75: 642-647.

Griz LMS, Machado ICS, Tabarelli M. 2002. Ecologia de dispersão de sementes: progressos e perspectivas. In: Tabarelli M, Silva JMC. (orgs.) Diagnóstico da Biodiversidade de Pernambuco. vol. 2. Recife, Secretaria de Ciência, Tecnologia e Meio Ambiente, Fundação Joaquim Nabuco e Editora Massangana. p. 597-608.

Guevara S, Laborde J. 1993. Monitoring seed dispersal at isolated standing trees in tropical pastures; consequences for local species availability. Vegetatio 107/108: 319-338.

Guevara S, Meave J, Moreno-Casasola P, Laborde J. 1992. Floristic composition and structure of vegetation under isolated trees in neotropical pastures. Journal of Vegetation Science 3: 655-664.

Guisan A, Zimmermann NE. 2000. Predictive habitat distribution models in ecology. Ecological Modelling 135: 147-186.

Harvey CA. 2000. Windbreaks enhance seed dispersal into agricultural landscapes in Monteverde, Costa Rica. Ecological Applications 10: 155-173.

Harvey CA, Haber WA. 1999. Remnant trees and the conservation of biodiversity in Costa Rican pastures. Agroforest Systems 44: 37-68.

Harvey CA, Tucker N, Estrada A. 2004. Live fences, isolated trees and windbreaks: tools for conserving biodiversity in fragmented tropical landscapes? In: Schroth G, Fonseca GAB, Harvey CA, Gascon C, Vasconcelos HL, Izac AMN. (eds.) Agroforestry and Biodiversity Conservation in Tropical Landscapes. Washington, Island Press. $\mathrm{p}$ 261-289.

Holl KD. 1998. Do bird perching structures elevate seed rain and seedling establishment in abandoned tropical pasture? Restoration Ecology 6: 253-261.

Holl KD. 1999. Factors limiting tropical rain forest regeneration in abandoned pasture: seed rain, seed germination, microclimate, and soil. Biotropica 31: 229-242.

Holl KD, Loik ME, Lin EHV, Samuels IA. 2000. Tropical montane forest restoration in costa rica: overcoming barriers to dispersal and establishment. Restoration Ecology 8: 339-349.

Janzen DH. 1970. Herbivores and the number of tree species in tropical forests. American Naturalist 104: 501-528.

Laurance WF, Lovejoy TE, Vasconcelos HL, et al. 2002. Ecosystem decay of Amazonian forest fragments: a 22-year investigation. Conservation Biology 16: 605-618.

Luck GW, Daily GC. 2003. Tropical countryside bird assemblages: richness, composition, and foraging differ by landscape context. Ecological Applications 13: 235-247.

Maarel E. 2005. Vegetation ecology. Oxford, Blackwell Publishing.

Martínez-Garza C, Flores-Palacios A, Peña-Domene M, Howe HF. 2009. Seed rain in a tropical agricultural landscape. Journal of Tropical Ecology 25: 541-550. 


\section{Driélli de Carvalho Vergne, Hisaias Souza Almeida, Caroline Cambraia Furtado Campos, Natália. S. Martins and Flavio Nunes Ramos}

Mazurek MJ, Zielinski WJ. 2004. Individual legacy trees influence vertebrate wildlife diversity in commercial forests. Forest Ecology and Management 193: 321-334.

McClanahan TR, Wolfe RW. 1987. Dispersal of ornithochorous seeds from forest edges in Central Florida. Vegetation 71: 107-112.

McDonnell MJ, Stiles EW. 1983. The structural complexity of old field vegetation and the recruitment of bird-dispersed plant species. Oecologia 56: 109-116.

McDonnell MJ. 1986. Old field vegetation height and the dispersal pattern of bird-disseminated woody plants. Bulletin of the Torrey Botanical Club 113: 6-11.

Metzger JP. 2000. Tree functional group richness and landscape structure in a Brazilian tropical fragmented landscape. Ecology Applications 10: 1147-1161.

Nason JD, Hamrick JL. 1997. Reproductive and genetic consequences of forest fragmentation: two case studies of neotropical canopy trees. Journal of Heredity 88: 264-276.

Nepstad DC, Moutinho PR, Uhl C, Vieira IC, Silva JMC. 1996. The ecological importance of forest remnants in an Eastern Amazonian frontier landscape. In: Schelhas J, Greenberg R. (eds.) Forest patches in tropical landscapes. Washington, Island Press. p 133-150.

Olivetti D, Mincato RL, Ayer JEB, Silva MLN, Curi N. 2015. Modelagem espacial e temporal da erosão hídrica em Latossolo vermelho distrófico com uso agropecuário numa sub-bacia hidrográfica do sul de Minas Gerais. Ciência e Agrotecnologia 39: 58-67.

Otero-Arnaiz AS, Castilho S, Meave J, Ibarra-Manriquez G. 1999. Isolated pasture trees and the vegetation under their canopies in the Chiapas coastal plain, México. Biotropica 31: 243-2254.

Peña-Domene M, Martínez-Garza C, Palmas-Pérez S, Rivas-Alonso E, Howe HF. 2014. Roles of birds and bats in early tropical-forest restoration. PLoS ONE 9: e104656. doi:10.1371/journal.pone.0104656.

Perfecto I, Rice RA, Greenberg R, Voort ME. 1996. Shade coffee: a disappearing refuge for biodiversity. BioScience 46: 598-608.
Pijl L. 1982. Principles of dispersal in higher plants. 3rd. edn. New York, Springer Verlag.

Rhoades CC, Erkert GE, Coleman DC. 1998. Effect of pasture trees on soil nitrogen and organic matter: implications for tropical montane forest restoration. Restoration Ecology 6: 262-270.

Ricketts TH. 2001. The matrix matters: effective isolation in fragmented landscapes. The American Naturalist 158: 87-99.

Roland J, Keyghobadi N, Fownes S. 2000. Alpine parnassius butterfly dispersal: effects of landscape and population size. Ecology 81: 16421653.

Sarmiento FO. 1997. Arrested succession in pastures hinders regeneration of Tropandean forests and shreds mountain landscapes. Environmental Conservation 24: 14-23.

Slocum MG, Horvitz CC. 2000. Seed arrival under different genera of trees in a neotropical pasture. Plant Ecology 149: 51-62.

Tewksbury JJ, Levey DJ, Haddad NM, et al. 2002. Corridors affect plants, animals, and their interactions in fragmented landscapes. Proceedings of the National Academic of Science 99: 12923-12926.

Tischendorf L, Fahrig L. 2001. On the use of connectivity measures in spatial ecology. A reply. Oikos 95: 152-155.

Vieira BLM, Aquino FG, Brito MA, Fernandes-Bulhão C, Henriques RPB. 2002. Síndromes de dispersão de espécies arbustivo-arbóreas do cerrado sensu strictu e savanas amazônicas. Revista Brasileira de Botanica 25: 215-220.

Wegner JF, Merriam G. 1979. Movements of birds and small mammals between a wood and adjoining farmland habitats. Journal of Applied Ecology 16: 349-357.

Wilson MV. 1993. Dispersal mode, seed shadows and colonization patterns. Vegetation, Ames 107: 261-280.

Wunderle JM. 1997. The role of animal seed dispersal in accelerating native forest regeneration on degraded tropical lands. Forest Ecology Management 99: 223-235. 